\title{
A Marxist Reading of William Blake's Selected Poetry: Machineries in Green Studies
}

\section{OPEN ACCESS}

Manuscript ID:

ENG-2021-09023625

Volume: 9

Issue: 2

Month: March

Year: 2021

P-ISSN: 2320-2645

E-ISSN: 2582-3531

Received: 12.12.2020

Accepted: 20.01.2021

Published: 01.03.2021

Citation:

Abdulla-Al-Mamun, Md.

"A Marxist Reading of William Blake's Selected

Poetry: Machineries in Green Studies." Shanlax International Journal of English, vol. 9, no. 2, 2021, pp. 7-17.

DOI:

https://doi.org/10.34293/ english.v9i2.3625

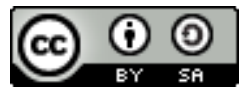

This work is licensed under a Creative Commons Attribution-ShareAlike 4.0 International License

\author{
Md. Abdulla-Al-Mamun \\ Lecturer, Department of English, Presidency University, Gulshan, Dhaka, Bangladesh \\ D https://orcid.org/0000-0003-1296-570X
}

\begin{abstract}
Being a dweller of Romantic ecology, William Blake familiarizes his readers with the slant of pastoral landscapes through the ecological sensibilities within the promiscuous city. In his poetry, he has speculated the adventurous plantation of slums in the metropolitan city in the light of machineries and matters that pack human in the box of ambitious dreams as the monstrous dreams of the metropolitan historicity root up the pastoral landscapes of Britain. Whereas critics engage themselves to explore the relation to the outcome of numerous English cultural dominations within his poetry, this study revisits the selected 'ecopoetics' through the lens of Marxism to explore the threats towards the green world, especially, within the city shore on Thames. Blake as a 'green prophet' enunciates the rural life that is pulverized by the mobility of the mechanistic forces of city life. These mechanistic forces are manipulated by the power of government, industrial revolution, commerce, and neo-colonialism in every day's behavior in order to ensure the submissiveness of the working class in 18th century England. Thus, the paper aims to discuss the Marxist narratives of Blake's 'ecosophy' that warns us against the severe repercussion of machines and its tyrannical reverberations over the marginalized in his selected poetry.
\end{abstract}

Keywords: Machines, Government, Industrial Revolution, Commerce, Neo-colonialism

As travelers in this biosphere, we are in a roller-coaster of theories in literary studies. The literary studies flux with ideas constantly, somewhat instantaneously, in this post-modern age as the machine comes in the lives of the Romantic age overnight. Recently, the discussion on the texture of English literature needs to re-frame in order to be congruent with the changing delineations of the theoretical studies. Ecology, the park of environmental literary studies, was planted in the mid-eighties of twentieth-century to be inclined to foster "a greater presence of environmental concern and awareness in literary disciplines" (Frederick 5). Simply, as Cheryll Glotfelty puts it, the fresh term 'ecocriticism' speaks about"the study of the relationship between literature and physical environment" (Glotfelty XVIII). However, this ecological approach divides within a very short tenure by its critics into two national variants - the preferred American coin is 'ecocriticism' and the frequently used for Britain is 'green studies'. 'Green studies' is one of the emergent and revisionist movements in literary discussion, which has cast its light on texts to bring out the arts and states of the earth till to-date. It applies a discourse where the reader can get ways to experience the relationship between human culture and nature. As a coin of "the British variant tends to be more "minatory", that is, it seeks to warn us of environmental threats emanating from governmental, industrial, commercial, and neo-colonial forces" (Barry 242). 
In the study on Blake's poems- "London", "Night", "A War Song to Englishmen", "The Little Vagabond", "The Chimney-sweeper", "The Little Black Boy", and "The Tyger", the Marxist interpretation mirrors the social and political values of the texts that underpin the view of class constructs relating to the coercive hegemony to perpetuate the propaganda of the superstructure on its base. Having the striking portrayal of the ecological threats, Blake's poems are to posit the complex identities of human values through the lens of Marxist narratives. The values inaugurate a clash highlighting the class consciousness, the divergent labor structure, and the laudable development of machine technology in the social and economic environment. To be more embodied, according to the critic Philip H. Vaughan, the "clash between pastoral and industrial-urban living" (424) as it "becomes an angry repudiation of industrial life as destructive to human values" (422). Addressing the clash between urban and rural life, Blake dramatizes his voice for the peripheral's pain through his use of prophetic imagination and vision. Since he articulates the perilous relation among capitalists, laborers, and machine, his speakers approach to the readers as an enigma not only to explore the anomalies of the English society but also to portray the environmental concerns. The reading reveals more violent action on the marginalized class and the landscape by using capitalistic industrial machines. The distortion of pastoralism is substantiated when he conflates the social view as "a kind of greed that manifests itself as a violence to the land, a transgression of Nature" (Margolies xiv). However, the notion of greed is generated from the both class - upper and lower - where the former one captivates a materialistic luxurious lifestyle and the later one dreams to have that lifestyle.

Britain represents itself in a great harmony of traditional green society where individual paints farmlands, wild lives, mountains, and flowers that carry an intense relationship with human activity before auctioning his or her life for the materialistic advancement to the capitalist authority. In his poetry, Blake emphasizes on the harmony in between the humanity and the beauty of nature, but later on, his pastoral imageries turn into apocalypse rapidly and shadow death for both entities. He, being romanticist, indicates his poetry as the rebirth of green consciousness which permeates the story where some fatal amalgamations of Bacon, Descartes, and the scientific revolution beclouds and takes the place of an organic and animistic English nature of the eighteenth century as machine afore the world. Indeed, in the latter half of the 18th century and the first half of the 19th century, the dominations of the government and the cruelty of the Church are implemented to its inhabitants in their disinclination of accepting the bitter dream of the authority. An observer of the British government may experience that the government terrifically chains the fundamental rights- voting- of men and women to gain their dim political agenda and make trash their lives on a wide scale. Young men are flooded by thousand of numbers every year, particularly, in London to work as novices under the capitalists and in their companies' machines. Others make possible to employ themselves as domestic workers in building sophisticated homes for aristocratic families. It witnesses the mount of monetary interest through the lens of political agenda during the volatile period as the pre-eminent 19 th-century society. Thus emerges the criticism on social and political notions which have been stemmed from Blake's imagination as well as critical perspective. By the inauguration and advancement of machine and technology, this society approaches to the inevitable cultural materialism with the tension of industrialization that leads to social hell. During the industrial revolution, dwellers are growing as an individual in the state of their mind when London is under the concern as a center of the capitalist world. The upper lifestyle has access to modern amenities like developed transport communication, luxurious goods, and mechanized urbanization. On the opposite, the exploitation of the capitalist and class conflict, low wages and hard labor-especially child labor-and dark burning ashes marginalize the working families in their daily life. The diverse exploitations categorize the living being at two poles under the stem of town where the certain are privileged and others are ostracized. As a result, commoners have accumulated regretful memories of shifting the conventional English feudal society where the melancholic tension is at the hand of the fraudulent mercantile economy and 
the agitation is in the dependents' consciousness. Similar polemic characteristics of the conditions of England summon antagonisms- "utilitarian and Romantic, science and feeling, the 'march of mind' and nostalgic medievalism, the cash nexus and moral economy" (Connell 4) - that have the traditional understanding to encapsulate the focal concentration of its vitriolic social criticisms. In this regard, Blake comes into the mind of his reader as a 'prophet' as his poetry evidently indicates the sign of threat, danger, injustice, and bleakness towards nature and its elements throughout the application of machines in human life. He portrays the danger of an individual's social life where machines control them under the city life that comes up vividly in his writings. The dichotomies of the class constructs having intrinsic values of the English society gloss over in the Blake's poems. Thus, he is acknowledged as an intellectual in the parallel way of visioning the coercive organization of the social system and of warning the future world, at least the terrible destiny of the English society.Consequently,the study within Blake's selected poetry warns us about the severe consequences of the mistreatment towards the commoners due to the hidden materialistic orientation inside the capitalists, the authority of the church, and the government resulting in the deprived people's immeasurable poverty and sorrows in their daily city life.

\section{Governmental Attitude}

William Blake is a 'prophet' who searches for the complication and miseries of ordinary human life questioning social and political issues of the 18th century England. The industrial wasteland reveals the political agendas to make aware the class consciousness of the superstructure- ruling class. In his writings, he paints the sorrows of the marginalized being a future teller to the reader that leads the reader to appreciate his understanding about the individual's own attitude about the domestic institutions. Illuminating the polarizing frameworks of machines and pastoralism, the Marxist narratives downplay the ecological discourses.

"London", as a mainstream national issue, is a poem of Blake from Songs of Innocence that unconditionally deals with the political background of English society that replaces the pastoral life with the machine by its cruelty to make privilege to the minimal number of the inhabitants. The inhabitants, being capitalists and owners of the machine, involve themselves to exploit the rural people engaging them in prompt production offering low wages which make threats and demolish the urbanization and its beauty. However, he doesn't explicitly accuse the authoritative system, government, whereas, the commoners too are responsible for their individual imprisonment behind the black concrete wall. In the very opening of "London", Blake scolds the government implicitly for favoring the higher class who are posing them against nature owning manufacturing machine excessively as well as suppressing the labor class extremely. The lines come in the beginning to light up the issues relating to the political beliefs of English in the following:

I wander thro' each charter'd street,

Near where the charter'd Thames does flow.

And mark in every face I meet

Marks of weakness, marks of woe.

(Johnson and Grant 53)

The city is classified, one-sighted, and beclouded where life is pre-destined and treated as a product of exchange by low wage. A somber atmosphere comes in the reader whenever they make the journey through the words like 'wander', 'charter'd', 'mark' in the opening of the "London". Blake shows his agitation towards the upper class using the repetition of 'chater'd' which favors reinforcing the ownership and privileges of distinctive class. It expresses the unequal notions of the authority in everywhere when they practice the repressive conduct towards the deprived people. The street and the river in London should be for every citizen because these symbolize fundamental rights, life, and equality in practicing power where these are owned by the affluent and are redesigned in order to offer welfares for the certain community. The metaphorical presentation of the street and Thames express the idea of repression, corruption, obstruction in the mechanistic city life. Here, the life is counted, explored, and structured by the extremely politicized governmental authority. This structure makes the journey of the people isolated through 'wander[ing]' in the materialistic town. The domination over the street and the 
Thames by the industrialists restrict the individual liberty that represents the 'weakness' and 'woe' of the majority as the working class in the society. The industrialists being privileged due to the corruption of the government wildly suppress the poor people overthrowing their fundamental rights. As opposed to, the commoners are suffering in their life because they can't have the ability to change their fortune keeping themselves in excessive workload. Even, it haunts the dream of the commoners who travel in the hope of better living opportunities from country to city. Thus, the town life of England, especially in London, becomes the plot of isolation, class distinction, humiliation, exploitation in the calm life of the migrated countrymen. The parting tone of the men comes in the vivid vision of "Night" from Songs of Innocence in this expression:

Farewell green fields and happy groves,
Where flocks have took delight;
Where lambs have nibbled silent moves
The feet of angels bright;
Unseen they pour blessing,
And joy without ceasing,
On each bud and blossom,
And each sleeping bosom.

(Johnson and Grant 33)

The guardian, ecology, of the world sprinkles its beauty through the nature writing of Blake. He illuminates the reminiscence through the child's voice but in the view of a mature observer in the 'Night'. In reminiscence, the villagers illustrate the nature as blessings for the world where green view waits to provide happiness unconditionally to its living being. It gives the delight, comfort, and protection to generate the co-existence among the entire creatures in the ecosphere. However, the commoners have started to relocate the memories in their materialistic, politicized, conservative, and miserable city life.The paradigm of scientific ecology-a move from organismic nature towards human-made ecological catastrophes- navigate the commoners to turn away from the pastoral to what Donald Worsternames a more materialist "energybased economics of nature" (Nature's Economy 306).

Blake, in a way, shows the journey of the commoners in his poetry and, on the other way, attracts the reader to understand the realistic point of view of the city- London- where he indicates the cold views of the Church of England and the despotism of the government towards the majority of the society. He pictures the pressure of the Church and the government in his emotions and approaches to describe the dire conditions of the poor peoplethe infant, the chimney-sweeper, the soldier, and the harlot- while wandering in the city of London as a speaker. He develops a grim picture of 18th century England in the narration of the third stanza of 'London':

How the Chimney-sweeper's cry

Every blacking Church appalls,

And the hapless Soldier's sigh,

Runs in blood down Palace walls.

(Johnson and Grant 53)

The chimney-sweeper, soldier, and harlot are the inhabitants of contemporary English society. So, Blake doesn't use the oppressive situation to exhibit the single of them rather he means every group of them. He uses the capitalizations of the 'Church', 'Soldier' and 'Palace' to have the substantiation that these mean a very deeper suggestion "that the whole of the urbanized society has gone to the state of the moral decay and misery" (Zahan 1613). Idealistically, the Church and government are the representation of the social institution where everyone will have the right to access to get mental peace and security in an equal state. Contrary, the institution for mental peace and security for citizens act likewise the only friend for the rich in the society. He points the Church as blackening when it permits child labor and exploitation of them on a wide scale to deform their physical structure. Thus, the Church appalls to the chimney-sweeper who is "very dear to Blake and immediately familiar to even the most casual reader of any of his works" (Makdisi 105). On the other hand, the 'Palace' which is the synonym of the English monarchy directs the dreadful power structure in England to evoke the 'soldier's sigh' in the wartime. Even, in the moment of the national crisis, the ruling class forces the labor class to join the army as the soldier where they become the major officers to dominate them. Soldiers only have to face the enemies along with their guns whether they are alive or not, it doesn't mean a lot to the officers or the 'Palace'. The similar atmosphere of the monarchy 
comes in "A War Song to Englishmen" on the following expression:

Prepare, prepare the iron helm of war,

Bring forth the lots, cast in the spacious orb;

(Johnson and Grant 10)

Ironically, the power class commences the war and the capitalist patronize it for their own monetary and materialistic privilege but the soldiers are forcefully entrapped to earn their bread and butter only for the sake of reinforcing the royal family. The wretched conditions of the soldiers emphasize their 'weakness' and 'woe' in their own state. So, the metaphorical presentation of the monarchy nothing but another phrase of oppression towards the poor family when it expresses:

His loyal queen shall rise, and welcome us!

Prepare, prepare.

(Johnson and Grant 10)

In “A War Song to Englishmen", the last two lines of the final stanza clarify the authority as tyrannical in the history of England. The monarchy calls a war for the humankind and invites to welcome the soldier that is truly hypocritical conduct to the nation. The ruling class believes that war can demolish the repression of the whole nation but preparing the soldier only from the lower community sheds light on the hidden cynical mapping of the government. Government goes silent when it is about the rich as well as the Church remains cold to serve the poor people in the English society. Blake indicates the Church as cold and the government as tyrannical in the voice of a little boy in his other poem called "The Little Vagabond". The coldness and tyranny exhibit in the very premier two lines:

Dear Mother, dear Mother, The Church is cold.

But the Ale-house is healthy \& pleasant \& warm;

(Johnson and Grant 52)

In the voice of a little vagabond, Blake calls Mother Mary, to place his critical concern related to the social institutions which are responding against of the poverty-stricken people in England. His 'prophetic' view through the lens of the hegemonic power structure allows him to illustrate the society as corrupt, oppressive with the reinforcement of the machines and its owners towards the commoners. The unethical attitudes of the corrupted and polluted city emerge the materialist ontology as well as the environmental distortion by linking the ecocritical threats to exploitative class policies in the poems. It encapsulates the values of the ecologist to expect about ethics that it "changes the role of Homo sapiens from conqueror of the land-community to plain member and citizen of it" (Leopold 240). Thus, Blake's eco-critical ethics emphasizes on the conflicts among class, labor, and industrial capitalism that endanger the organismic park.

\section{Industrial Revolution}

Blake opines that the Industrial Revolution has a resilient effect in the city life of its inhabitants during the 18th-century England. The manufacturers inaugurate machines on a large scale to escalate the quantity of the product under the very filthy and polluted circumstance of the factories. The black dust comes out of the factories and mingles in the air as well as in the lifestyle of city dwellers. Simultaneously, the polluted smoke has left severe consequences like unhealthy, unhygienic living conditions for the residents in the society. In the same way, the river Thames, the heart of London, has been devastated by the byproducts of the industries. The industrialists start gaining the monetary luxury whereas the workers still in the face of death to ensure their least fundamental rights. So, they work in exchange of low wage that seems to be exploited by the dominants who become, later, the capitalists and celebrate this domination as a culture propaganda in according to the theory of Karl Marx. According to the Italian communist Antonio Gramsci, the propaganda of ruling class is used by the idea of 'hegemony' where the domination is coercive and oppressive, as well as the oppression comes within the consent of the dominant (Dyk). Raymond Williams, a cultural critic, highlights in Marxism and Literature (1977) that every history has its own hegemonies. The most leading hegemony mechanizes for the ruling class, the residual hegemony stands in favor of the culture and belief system of the earlier age, and the emergent hegemony leaves a position that may be dominant in the forthcoming age. However, the cry of the poor people due to the dominant hegemony spread like bush fire all of a sudden when money flies for the certain tyrants. Blake's "London" depicts the cry as a result of the threats of the machine over the natural world within the outcome of the Industrial 
Revolution in the first stanza following:

I wander thro' each charter'd street,

Near where the charter'd Thames does flow.

And mark in every face I meet

Marks of weakness, marks of woe.

(Johnson and Grant 53)

London is the city where people live for economic freedom in every day's life. The heart of the economy turns the opposite direction to provide advantages to the affluent in the wind of the Industrial Revolution. The city holds its opportunities for the owner of the private property with the support of the monarchy. The street and the Thames are the public ownership for the English society but Blake uses the word 'charter'd' to mean the ownership is leased by the power practitioners' to have control over the commoners like the machines in the factory. The idea of 'chater' d' fetches luxurious happiness only to the English tradesmen, businessmen, and government. The lower class, oppositely, bears the sufferings and pain by the corrupted dictators who are controlling the public property in the name of manufacturing lavishness for modern life. Every one of the marginalized community is under the hammer of their miserable life due to the ill-treatment, corrupted politics, and overly mechanistic production by the suppressors. Coupled with the tyrannical idea in "London", another poem from Songs of Innocence"The Chimney-sweeper"-holds the consequence of the oppression of industry towards the working class in its first stanza in the following verse:

When my mother died I was very young,

And my father sold me while yet my tongue

Could scarcely cry weep weep weep weep.

So your chimneys I sweep \& in soot I sleep.

(Johnson and Grant 25)

The poet illustrates the somber atmosphere in the speech of a little boy who is in the face of terrible havoc of economic inequalities in the Industrial Revolution. The boy speaks being the representative of the repressed community in the English society. The speaker as a little boy losses his mother in the very early stage in this self-centered realistic world. He has been sold by his father because of the spiritual poverty that grasps the rational part of the human being. Blake shows that the boy has to live his life taking risk by chimney-sweeping which can cause his physical deformity and even his death too. The poignant remark is that sweeper can utter only 'weep' several times instead of 'sweep' in his exploitation even. The exploitation turns into the synonym of the working class when they can't raise their voice to stand against industrial exploitation. Therefore, the child exploitation calls the Church 'blackening' in the first two lines of the third stanza of "London" as the expression comes:

How the Chimney-sweeper's cry

Every blackening Church appalls,

(Johnson and Grant 53)

The Church is titled as 'blackening' by the same token as the factories blacken the low wage earners. In the definition of the Church, friendly attitudes come with the serving viewpoint, in reality; it approaches to the being as the media of the dominant figure. It fails to acclimatize the rapid novelties in the rural community within the 18th-century English society. Consequently, the Church can't convey the spiritual needs growing in the industrial towns under the menace of machine among the ordinary people. The condition of a vital social institution casts lights to portray the critical concern of the exploited townsman that "the Church of England did not recognize the problems of these towns and many priests belonged to the gentry and shared the opinions of the government and the ruling class [...] The Church of England itself showed little interest in the social and spiritual needs of the growing population" (McDowall 123-124).

The selected poems of Blake reveal the portrayal of the chaos and anarchy regarding the blurred dichotomies between economics and ecology in the form of a gloomy and grim shadow of the marginalized class. The persecution of the scientific inventions causes the lifestyle of the dwellers to live with machines and materialistic dreams. However, along with the domination of the scientific inventions, the deliberate negligence of the industrialists towards the spiritual and physical needs of the working class imprisons the human soul rather than liberating them. Consequently, the man-made catastrophes of machines are the "inevitable outcome of a [capitalist] culture that deliberately, self-consciously, set itself the task of dominating and exploiting the land for all it was worth" (Worster4). The selected poems"London", "The Chimney-sweeper"- of Blake, in 
this regard, draws the psychological trauma along with the physical imprisonment of the ordinary men that comes working like machines in the industrial society.

\section{Commercial Perspective}

During the 18th century, the Industrial Revolution fuels the consumerism of the inhabitants all through England. Though the consumers are classified in various levels of trades where money has a different speed of flows in the market. The flows determine the privileges one can enjoy and the domination over the other classes in the materialistic world. The tradesman and rulers always muscularly claim to stand the opposite of the mirror in the system of the authority. The glamour of the gloom covers the oppression in the working environment. Thus, it evokes a brutality of commerce to create a sense among them to enjoy the public privileges in a monopolistic way without being embarrassed to the marked faces who are in 'weakness' and 'woe'. Blake sees the London in the eyes of the penurious, as he writes:

I wander thro' each charter'd street,

Near where the charter'd Thames does flow.

And mark in every face I meet

Marks of weakness, marks of woe.

(Johnson and Grant 53)

The street and the Thames are mentioned here as the property for public purposes. The control over the street and the Thames which are the public property are in the grip of the industrialist and the authority to enjoy privileges for their own benefits. The word 'charter'd' provides rights only to tradesmen to operate their desire in the city life taking away the freedom of fundamental equality from locals. It leads to the idea of 'monopolized commerce' which is contrary to the balance of equal treatment in the society. As a result, the 'monopolistic privileges' allow the rulers to be more autocrat over the commoners by designing the hypocritical act of showing the dream of luxurious life. So, the last two lines of this stanza hold the repressive picture of the society that the appearance of everyone's face displays the mark of 'weakness' and 'woe'. The monopolistic authority of the system of "London" has been cursed for allocating commercial privileges to the tradesmen in the fourth and last stanza in the following:
But most thro' midnight streets I hear
How the youthful Harlot's curse
Blasts the new-born Infant's tear
And blights with plagues the Marriage hearse.

(Johnson and Grant 53)

The stanza starts with its arguments that sheds light to the dreadful event of the society where many young women curse for experiencing the sinful trade in England due to its poverty and the materialistic attitude of the aristocrats. Blake attempts to compare the cry of prostitutes to the working class in everywhere of London. Prostitution turns into a visible domestic life for young and street women in London. The women suffer from their livelihood like the other street job seeker- chimney-sweeper, beggar, porter, or worker- in the English society. It seems women are in the same miserable life likewise other inhabitants when desperately "they were on the verge of starvation", so "the boundary between begging and working was always a very subtle one. Frequently women would go from door to door, asking for broken or a bit household work"(Hitchcock 80-81). As the elite class enjoys the maximum luxurious modern amenities, poverty approaches its wheel in the stormy speed in an intention of grasping the fundamental rights of the dependents in a wide measure like the machine does in the 18th century to produce products for the city dwellers in a large number of scales. Critics often find "a strong correlation between poverty and prostitution" (Gray 129) and drag a resolution that the former brings someone to the latter for living life in the society. Women, who are in the stigmatized action during the midnight of London exchanging money for commercial pleasure, are just the object of charity in the attitudes of men in Blake's contemporary time. However, it is well experienced from the history of 18th century England that all women are not professional prostitutes rather others live in sin with men because of having monetary profit to live well on a sunny day during the povertystricken period of England. The speaker epitomizes the sufferings of the harlot and their curse towards the birth of the infant and the traditional marriage. She curses because they are in a miserable life so 
if their infant comes, they will be in grim life too. Therefore, birth and marriage are not a happy cycle of life rather these are a cynical emblem of living in the society. The ideal belief of marriage is in binary mood likewise the English society provides the privileges for its tenants in multi classes. The married women should have been in monogamy whereas the men have the scopes to enjoy their life physically and psychologically spending charitable offerings for various 'street women' who satisfy them in both ways. The disdainful perspective of the men under the vision of the capitalist works as the raw materials and fires up the peripherals that map a critical contest among the inhabitants of the England.

The classical Marxist discourse requires the three elements-raw materials, labor, and machines-to comprehend the value of any product. Surprisingly, the raw materials stands in the epicenter to call a competition between the labor of the worker and the machines whenever "the instrument of labor, when it takes the form of a machine, immediately becomes a competitor of the worker himself" (Marx 557). Consequently, "London" is discussed to unfold the outcome of the contest- prostitution, baby's tear, and marriage- indicating that the marginalized are in the repression through the capitalist view of the privileged men due to the defeat in the contest. Thus, machines captures the synonymous position of the dominant in the society and becomes the ultimate destroyer of the ecosystem in the biosphere. Blake being the voice of the depressed soul of the society and the nature displays the repression of the exploited self and declares the poignant faces of the commercial agents.

\section{Neo-colonial Force}

Neo-colonialism traces its ideological forces that change several norms and ideas on the social, cultural, and political views of contemporary English society. The dissensions on neo-colonialism are incredibly bourgeoning among its critics as the English monarchy is approaching in various cities, especially on dependencies, with different mechanistic purposes. This new coin is appreciated in some localities, while some criticize it on the concern of using the economic, political, social, and cultural forces of the authority to bulldoze the labor class in the factory, home, and everywhere they are found in physical existence. The Marxian understanding sees the force as a continuous and constantly transforming property. Due to the industrial machinery, the perpetual process of harvesting the luxurious amenities remains static only to the authority that drives the culture of colonialism and imperialism, which accelerate the exploitation of the race and class, and therefore capitalism. Undoubtedly, the capitalist mindset accept that "the role of culture is much more expansive, that human beings have limitless potential, and that the key to economic growth is to enable and unleash that potential" (Florida 5).

In the poetry of Blake, he represents the mute response of the ruling class as meditative support to the repressive system on the commoners as a result of the enslavement in the English garden. The beginning of "The Little Black Boy" from Songs of Innocence reveals the cultural maltreatment against children as the voice of the lower class in the society in the following:

My mother bore me in the southern wild,

And I am black, but O! my soul is white.

White as an angel is the English child:

(Johnson and Grant 22)

Although the voice of the poem is from Songs of Innocence, it starts with the experience tone that is the evidence of the tormenting view of neo-colonialism which stands against the society. In the 18th century, the economic power of London is at the hand of the white people who control the majority of the society under their factory enslaving the black workers from other cities by paying low wages and pressurizing to work for long hours. So, the belief comes in the mind of the speaker, here, that the city holds a culture of racial difference which is corrupted and contradictory for humankind while exhibiting the depressed souls of a mother and the little boy in their frustrated conversation. The voice raises a concern for all of us to revisit the English city through the poetry of Blake that "since the black boy recognizes the nationality of the white boy, he may already be one of those slaves brought to London as a young house servant by West Indian absentee landowners then sold to slavers going back to the islands when they grew older" (Gallant 126). The slave in the voice 
of the speaker expresses the threats of understanding the true connotation of 'black' and 'white'. In an ironic explanation, the black boy clarifies his journey from south in a submissive tone to the authority of the society that the aristocratic English culture- racial repression- taunts about his physical color due to the monetary aggression in the mechanistic world but his inner state is 'white' that color is considered as an angel still, especially, in London. The depression of the speaker comes out to the readers in the third line when his white soul is compared to 'the English child' declaring an English child like an angel to justify himself as an equal being of the English child. On the very concrete contrary understanding, it obviously conveys the substantiation of the cruelty of the machine-oriented authority to the little black boy who represents the marginalized group of the English society. Similarly, as the study progresses, the atrocity of machine, industry, and cultural issues are reflected in "The Tyger" devastatingly:

What the hammer? What the chain?

In what furnace was thy brain?

What the anvil? What dread grasp,

Dare its deadly terrors clasp?

(Johnson and Grant 49)

The semantic guidance through 'hammer', 'chain', 'furnace', and anvil' vividly relates to the use of industrial workers or the factory machine. In this stanza of "The Tyger", William Blake refers to the threat as forthcoming in the commoners' life because of the excessive use of iron and material as neo-colonial forces in the city life. The forges of the workers are the place where they are guided to be the puppet at the hand of the ruling class. Being the very radical critics of the upper class, he suggests that the revolution to stand against the oppression can only be produced by one individual's intellectual forge. However, the rational power of the lower class is chained and tortured by the tyrannical view of the political institutions. Likewise, the political attitudes in "London" trace the sufferings and discriminations only of the poor people being the voice of the metropolitan- London- as no man's land. The flourishing city life has been criticized for its miserable conditions in the second stanza:

In every cry of every Man,

In every Infants cry of fear,

In every voice: in every ban,
The mind-forg'd manacles I hear

(Johnson and Grant 53)

Blake creates a note of melancholy through the first-person perspective that evidently indicates the men are travelling in the street of neo-colonial power of the British government. The 'street' and the 'Thames' carry the neo-colonial political standpoint to run down the city life where everyone clashes finding themselves against machines with its poignant standpoint but regrettably can't raise their voice to alter their present grim condition. The speaker leaves the note to a point where he portrays the bleak view of London as 'no man's land' to justify every face who is in 'cry' because of the 'mind-forged manacles' throughout the city.

The ideological forces of neo-colonialism throughout the reading of Blake's poetry aim to expose the controlling view of the power class over the depressed poor people. The selected poetry "The Little Vagabond", "The Tyger", and "London" speak about the marginalized society which is the subject of slavery and poverty. Illuminating and emphasizing the effect of neo-colonial forces, Blake draws the line of his criticism that stands against the machine and cares for the oppressed people. The criticism thereby symbolizes the maltreatment towards the working class by the machine-oriented tyrants through neocolonial forces in his contemporaneous society.

\section{Conclusion}

The study, on the whole, draws that William Blake stands against the views of the aristocratic society which sprinkles the mephitis of machines due to the industrial capitalism on the relationship among the human. He criticizes the mechanistic lens in his poetry that incessantly explore the maltreatment of human as autocrat towards the nature which "seek to warn us of environmental threats emanating" (Barry 242) in a parallel manner by the corrupted thoughts and repressive authority of the city life over the commoners in the 18th century Britain. Being the hostile voice in Blake's poetry, the criticism advocates the ruinous tendencies of social bars that materialize the disharmony between different classes in the society where the authoritative propensities devastatingly highlight their opposite reaction against individual liberty of the ordinary human. The 
speakers of Blake in the poems explicitly identify the privatization of public liberty within the view of providing opportunities to the machine owners which reflect the antagonism of the orthodox power system of the society. Indeed, due to the cultural material fact in Blake's selected 'ecopoetics', the mercantilism along with the perspective of industrialism imprisons the mechanization of living in the English society both intellectually and physically and paralyzes the voice of the marginalized using a new conundrumneo-colonialism to deliver the materialistic privileges to the affluent who are in good books of the hegemonic politicians. Consequently, the corrupted politicians are 'othering' the wretched poor class to justify their good terms with the machine and factory that create rigorous trauma for Blake. As a result,he stands alongside the 'Other' through his critical voice in the poetry. The poems are the substantiation in this study to carry the accusations of the poet against of all the ruling political parties, industrialists, and mercantilists for 'othering' every one of the dependant race-infants, laborers, soldiers, men, and women. The poet views the misjudgment of the Church, war-trauma of the political hegemony, maltreatment towards the harlot, and death of the esthetic mind of the countrymen because of social institutions that are outrageously in touch of mechanistic forces. He bluntly displays his agony for the oppressed and marginalized in his 'ecopoetics' producing indignations for the governmental, industrial, commercial, and neo-colonial forces who devastatingly inject hegemonic machineries in order to accomplish the biotic violence in the 18th century English garden.

\section{References}

Attaway, William. Blood on the Forge. Collier Books, 1970.

Barry, Peter. Beginning Theory: An Introduction to Literary and Cultural Theory. Viva Books, 2010.

Bloom, Harold. William Blake. Infobase Publishing, 2008.

Connell, Philip. Romanticism, Economics and the Question of 'Culture'. Oxford University Press, 2005.
Florida, Richard. Cities and the Creative Class. Routledge, 2005.

Gallant, Christine. "Blake's Antislavery Designs for Songs of Innocence and of Experience." The Wordsworth Circle, vol. 35, no. 3, 2008, pp. 123-130.

Garrard, Greg. Ecocriticism. Routledge, 2004.

Gifford, Terry. Pastoral. Routledge, 1999.

Glotfelty, Cheryll, and Harold Fromm. The Ecocriticism Reader: Landmarks in Literary Ecology. University of Georgia Press, 1996.

Gray, Drew D. Crime, Prosecution and Social Relations. Palgrave Macmillan, 2009.

Hitchcock, Tim. Down and Out in EighteenthCentury London. Cambridge University Press, 2004.

Johnson, Mary Lynn, and John E. Grant. Blake's Poetry and Designs. W.W. Norton \& Company, 2008.

Leopold, Aldo. "The Land Ethic." A Sand County Almanac, Oxford University Press, 1949.

Makdisi, Saree. William Blake and the Impossible History of the 1790s. University of Chicago Press, 2002.

Marx, Karl. Capital. translated by Ben Fowkes, Penguin Books, 1976.

Marx, Leo. The Machine in the Garden: Technology and the Pastoral Ideal in America. Oxford University Press, 2000.

"Marxist Literary Theory." The Nature of Writing, www.natureofwriting.com/courses/writingabout-literature/lessons/marxist-literarytheory.

Mcdowall, David. An Illustrated History of Britain. Longman, 2006.

Vaughan, Philip H. "From Pastoralism to Industrial Antipathy in William Attaway's Blood on the Forge." Phylon, vol. 36, no. 4, 1975, pp. 422425.

Waage, Federick, O. Teaching Environmental Literature: Materials, Methods, Resources. Modern Language Association of America, 1985.

Williams, Raymond. Marxism and Literature. Oxford University Press, 1977.

Williams, Raymond. The Country and The City. Oxford University Press, 1975. 
Worster, Donald. Dust Bowl: The Southern Plains Zahn, Changjuan. "William Blake and his Poem in the 1930s. Oxford University Press, 2004.

Worster, Donald. Nature's Economy: The Roots of London." Theory and Practice in Language Ecology. Sierra Club Books, 1977. Studies, vol. 3, no. 9, 2003, pp. 1610-1614.

\section{Author Details}

Md. Abdulla-Al-Mamun, Lecturer, Department of English, Presidency University, Gulshan, Dhaka, Bangladesh EmailID: mr.sust88@gmail.com 